OPEN ACCESS

Edited by:

Tom Defoirdt,

Ghent University, Belgium

Reviewed by:

Evelien Wynendaele,

Ghent University, Belgium

Johann Mignolet,

Catholic University of Louvain,

Belgium

*Correspondence:

Zvi Hayouka

zvi.hayouka@mail.huji.ac.il

Specialty section:

This article was submitted to

Infectious Diseases,

a section of the journal

Frontiers in Microbiology

Received: 12 March 2019

Accepted: 20 May 2019

Published: 07 June 2019

Citation:

Yehuda A, Slamti L, Malach E, Lereclus D and Hayouka Z (2019)

Elucidating the Hot Spot Residues

of Quorum Sensing Peptidic Autoinducer PapR by Multiple Amino

Acid Replacements.

Front. Microbiol. 10:1246. doi: 10.3389/fmicb.2019.01246

\section{Elucidating the Hot Spot Residues of Quorum Sensing Peptidic Autoinducer PapR by Multiple Amino Acid Replacements}

\author{
Avishag Yehuda ${ }^{1}$, Leyla Slamti², Einav Malach ${ }^{1}$, Didier Lereclus ${ }^{2}$ and Zvi Hayouka ${ }^{1 *}$ \\ ${ }^{1}$ Institute of Biochemistry, Food Science and Nutrition, The Hebrew University of Jerusalem, Rehovot, Israel, ${ }^{2}$ Micalis \\ Institute, INRA, AgroParisTech, Université Paris-Saclay, Jouy-en-Josas, France
}

The quorum sensing (QS) system of Bacillus cereus, an opportunistic human pathogen, utilizes the autoinducing PapR peptide signal that mediates the activation of the pleiotropic virulence regulator PlcR. A set of synthetic 7-mer PapR-derived peptides $\left(\mathrm{PapR}_{7} ; \mathrm{ADLPFEF}\right)$ have been shown to inhibit efficiently the PlcR regulon activity and the production of virulence factors, reflected by a loss in hemolytic activity without affecting bacterial growth. Interestingly, these first potent synthetic inhibitors involved D-amino acid or alanine replacements of three amino acids; proline, glutamic acid, and phenylalanine of the heptapeptide PapR. To better understand the role of these three positions in PlcR activity, we report herein the second generation design, synthesis, and characterization of $\mathrm{PapR}_{7}$-derived combinations, alternate double and triple alanine and D-amino acids replacement at these positions. Our findings generate a new set of nonnative $\mathrm{PapR}_{7}$-derived peptides that inhibit the PlcR regulon activity and the production of virulence factors. Using the amino acids substitution strategy, we revealed the role of proline and glutamic acid on PlcR regulon activation. Moreover, we demonstrated that the D-Glutamic acid substitution was crucial for the design of stronger PlcR antagonists. These peptides represent potent synthetic inhibitors of $B$. cereus QS and constitute new and readily accessible chemical tools for the study of the PlcR system. Our method might be applied to other quorum sensing systems to design new anti-virulence agents.

Keywords: quorum sensing, quorum quenching, PIcR antagonists, B. cereus group, anti-virulence peptides

\section{INTRODUCTION}

Quorum sensing (QS) is a cell-cell communication mechanism used to coordinate bacterial group behaviors (conjugation, virulence, sporulation, or competence) by assessing cell density through the production, secretion, and detection of small signaling molecules (Dunny and Leonard, 1997; Miller and Bassler, 2001; Slamti et al., 2014). Gram-negative bacteria appear to predominantly respond to $\mathrm{N}$-acyl homoserine lactones, while QS in Gram-positive species mainly relies on the secretion of auto-inducing oligopeptides to bind and activate their cognate quorum sensors. In the past decade, a rapid increase of interest in bacterial quorum sensing peptides (QSPs) has emerged. Therefore, new QSPs databases are being established to provide chemical structures overview, microbial origin 
and functionality responses of these QS-derived signaling peptides (Gray et al., 2013; Wynendaele et al., 2013; Rajput et al., 2016).

The QSPs binding to their cognate quorum sensors occurs either on the outside of the bacterium (by interacting with a sensor in the membrane) or in the cytoplasm of the bacterial cell. In the latter case, the quorum-sensing regulators are controlled by direct interaction with a internalized signaling peptide (Dunny and Leonard, 1997; Lazazzera et al., 1997; Gominet et al., 2001; Miller and Bassler, 2001). They have been grouped in a new family of quorum sensors termed Rap-Rgg-NprR-PrgXPlcR (RRNPP; Declerck et al., 2007; Neiditch et al., 2017). These quorum sensors are characterized by the presence of structural tetratricopeptide repeats (TPRs) forming a peptide binding domain (Blatch and Lässle, 1999), and a helix-turnhelix (HTH) DNA-binding domain (Wintjens and Rooman, 1996) in the case of transcriptional regulators. The $\operatorname{PrgX}-$ cCF10 system regulates conjugation in Enterococcus faecalis (Suzuki et al., 1984; Shi et al., 2005), the Rap phosphatases$\mathrm{Phr}$ peptides system control competence and sporulation in Bacillus subtilis (Lazazzera et al., 1997; Perego and Brannigan, 2001; Perego, 2013), the transcriptional regulator/peptide pairs PlcR - PapR and NprR - NprX of the Bacillus cereus group are required for virulence and necrotrophism gene expression, respectively (Slamti and Lereclus, 2002; Perchat et al., 2011; Dubois et al., 2012; Grenha et al., 2013) and the archetype transcriptional regulator of the Rgg family, namely ComR that controls competence in most mutans, suis, pyogenes, bovis and salivarius streptococci (Mashburn-Warren et al., 2010; Fontaine et al., 2015) and predation in S. salivarius (Mignolet et al., 2018). The last discovered RRNPP transcriptional regulators are the PlcRa that activate the oxidative stress response and cysteine metabolism in transition state cells in B. cereus (Huillet et al., 2012) and aimR, which coordinates viruses of SPbeta group lysis-lysogeny decisions during infection of its Bacillus host cell (Erez et al., 2017).

The RRNPP family has an important role in adaptive and virulence processes in several bacteria (Slamti et al., 2014; Neiditch et al., 2017). This clearly identifies these regulators as major targets for the search of novel strategies against bacterial infections beyond conventional treatments. Antimicrobial therapy based on quorum quenching (QQ) can interfere or block all the processes involved in quorum sensing (Amara et al., 2011; Kalia, 2013; Grandclément et al., 2015). In contrast to antibiotics or antimicrobial agents, which aim at killing bacteria or inhibiting their growth, blocking cell-tocell signaling mechanism, could attenuate bacterial pathogenicity without imposing the level of selective pressure on a bacterial population to develop resistance (Suga and Smith, 2003; Rasmussen and Givskov, 2006). A wide range of promising molecules have been already identified to inhibit QS-controlled virulence genes in Gram-negative bacteria (Hentzer et al., 2003; Galloway et al., 2012). On the other hand, except for strategies that have been investigated to inhibit the two component QS system Agr of Staphylococcus, which uses a peptide-thiolactone as the extracellular signal, the design of molecules modulating QS systems in Gram-positive bacteria has been poorly explored
(Fontaine et al., 2010; Zheng et al., 2011; Tal-Gan et al., 2013a, 2014, 2016; Sully et al., 2014).

Bacillus cereus is a human opportunistic, Gram-positive sporeforming bacterial pathogen belonging to the $B$. cereus group (Stenfors Arnesen et al., 2008). This group comprises a number of highly phenotypically and genetically indistinguishable related species, including Bacillus thuringiensis, an insect pathogen, and Bacillus anthracis, the aetiological agent of anthrax (Helgason et al., 2000). The widespread presence of $B$. thuringiensis and $B$. cereus in soil and food, and their close relationship with B. anthracis make this group an important threat to public health (Rasko et al., 2005; Rossi et al., 2018), and a potential source of new pathogens. Indeed, B. cereus is generally regarded as a pathogen causing foodborne infections due to the production of enterotoxins such as $\mathrm{Hbl}$ and Nhe (Stenfors Arnesen et al., 2008), and nosocomial infections in an immuno-compromised patients (Granum and Lund, 1997; Kotiranta et al., 2000; Chu et al., 2001; Gaur et al., 2001; Bottone, 2010). B. cereus strains were also found to be responsible for severe infections resembling anthrax (Hoffmaster et al., 2004; Klee et al., 2006).

The QS system of $B$. cereus plays an important role in virulence (Agaisse et al., 1999; Gohar et al., 2008). B. cereus uses QS to establish infections by producing an arsenal of virulence factors, such as enterotoxins, pore-forming haemolysins, cytotoxins and various degradative enzymes (Granum and Lund, 1997; VilasBoas et al., 2002; Stenfors Arnesen et al., 2008; Ramarao and Sanchis, 2013). Production of most of these exported virulence factors is activated by PlcR, a $34 \mathrm{kDa}$ protein that acts as a $B$. cereus group main virulence transcription factor (Lereclus et al., 1996; Agaisse et al., 1999; ØKstad et al., 1999; Gohar et al., 2008). Activity of PlcR depends on the binding of the signaling C-terminal heptapeptide $\mathrm{PapR}_{7}$ (ADLPFEF) at the end of the exponential growth stage. $\mathrm{PapR}_{7}$ is imported by the oligopeptide permease system (OppABCDF; Gominet et al., 2001), binds the tetratricopeptide repeat (TPR)-type regulatory domain of PlcR (Grenha et al., 2013) and promotes recognition of the PlcR box to transcriptional activation of the target genes (Lereclus et al., 1996; Gominet et al., 2001; Slamti and Lereclus, 2002; Bouillaut et al., 2008). This triggers a positive feedback loop that up-regulates the expression of $p l c R, p a p R$ and various virulence genes (Agaisse et al., 1999; Ivanova et al., 2003; Gohar et al., 2008).

The structural and molecular basis for the activation of PlcR by PapR has been the focus of several studies, which have revealed interesting insights on the PlcR - PapR interactions. The PlcR - PapR relationship has been shown to be strain specific; comparison of the amino acid sequences of PlcR and PapR from 29 different strains demonstrated the existence of four classes (I to IV) of PlcR - PapR pairs, defining four distinct pherotypes in the B. cereus group. While PapR sequences from different strains of the $B$. cereus group showed divergences in their three N-terminal residues, the PFEF core was more conserved (Slamti and Lereclus, 2005). In 2007, the crystal structure of the complex formed between the protein PlcR (from group I) and the C-terminal $\mathrm{PapR}_{5}$ pentapeptide (LPFEF) was published (Declerck et al., 2007). According to RRNPP conserved features, each subunit of PlcR is formed of an N-terminal HTH DNA-binding domain, and a C-terminal regulatory domain 
composed of five degenerated TPRs forming a peptide binding domain. Binding of PapR triggers an allosteric mechanism that leads to a drastic conformational change of the HTH domains upon the two half sites of the DNA binding site, known as PlcR-box. The LPFEF pentapeptide, $\mathrm{PapR}_{5}$ was identified as the minimal peptide size required for PlcR activation (Slamti and Lereclus, 2002). However, the physiologically relevant heptapeptide $\mathrm{PapR}_{7}$ displays a slightly better affinity for $\mathrm{PlcR}$ (Bouillaut et al., 2008; Grenha et al., 2013). In 2008, Bouillaut and co-workers established a molecular model for the complex formed between PlcR and the heptapeptide $\mathrm{PapR}_{7}$ based on the crystal structure of $\mathrm{PapR}_{5}$-bound PlcR (Declerck et al., 2007; Bouillaut et al., 2008). Structural analysis and directed mutagenesis of $\mathrm{PlcR}$ residues suggested that: a) activation of $\mathrm{PlcR}$ by $\mathrm{PapR}_{7}$ is triggered by the hydrophobic interactions of the leucine, and two phenylalanines with helices 5 and 7 of the TPR-containing domain of $\mathrm{PlcR} b$ ) the central proline residue may be required for the PapR peptides to fit into the binding groove on $\mathrm{PlcR}$ and c) the glutamic acid of the FEF PapR core motif may function to selectively allow PapR to bind PlcR by ionic interactions with Lys87 and 89 . In a follow up study in 2013, Grenha and co-workers, have determined the crystal structure of the ternary complex DNA-PlcR-PapR $\mathrm{P}_{7}$. It has been reported that both $\mathrm{PapR}_{7}$ phenylalanine residues are located in hydrophobic pockets and the only specific interactions are made between the glutamate of $\mathrm{PapR}_{7}$ and residues Lys89, Gln237, and Tyr275 of PlcR.

Binding of PapR to PlcR is essential to trigger QS-mediated functions in $B$. cereus. Thus, we recently studied the PlcR PapR activation in B. cereus and B. thuringiensis at the molecular level. We designed, synthesized and characterized synthetic PapR 7-mer derived peptides to determine the contribution of each residue within $\mathrm{PlcR}-\mathrm{PapR}_{7}$ interactions. Our findings reveal the first set of non-native peptides that can repress the $\mathrm{PlcR}$ regulon and thus relevant virulence factors. Moreover, we could demonstrate that the repression is mediated by QS and regulation of $\mathrm{PlcR}$ expression without affecting bacterial growth (Yehuda et al., 2018). Interestingly, these first potent synthetic inhibitors involved $\mathrm{D}$-amino acid or alanine replacements of either proline (P) glutamic acid (E) or phenylalanine (F) of the heptapeptide PapR (ADLPFEF). To better understand the role of these three crucial positions in $\mathrm{PlcR}$ activation, we report herein the second generation design, synthesis, and characterization of $\mathrm{PapR}_{7}$-derived combinations, alternate double and triple alanine and D-amino acids replacement at these positions. We propose this systematic replacement approach to elucidate other quorum quenching agents in Gram-positive bacteria.

\section{MATERIALS AND METHODS}

\section{Bacterial Strains and Growth Conditions}

Bacterial strains used in this study: B. thuringiensis $407 \mathrm{Cry}^{-}$ $p l c A^{\prime} Z$ (Bt A'Z) and the PapR null-mutant $407 \mathrm{Cry}^{-} \Delta p a p R$ $p l c A^{\prime} Z$ (Bt $\triangle$ papR A'Z) strains, containing a transcriptional fusion between the promoter of $p l c A$ and the lac $Z$ reporter gene (as described previously; Gominet et al., 2001; Slamti and Lereclus, 2002); B. cereus strain ATCC 14579 (Ivanova et al., 2003). Unless otherwise noted, cells were grown in modified LB medium ( $16 \mathrm{~g} / \mathrm{L}$ tryptone, $8 \mathrm{~g} / \mathrm{L}$ yeast extract, $5 \mathrm{~g} / \mathrm{L} \mathrm{NaCl}$ ) at $37^{\circ} \mathrm{C}$ and stored at $-80^{\circ} \mathrm{C}$ in LB containing $25 \%$ glycerol. Kanamycin $(200 \mu \mathrm{g} / \mathrm{mL})$ was used for the selection of B. thuringiensis.

\section{Solid Phase Peptide Synthesis Methodology (SPPS)}

All the peptides were synthesized using standard Fmoc-based solid-phase peptide synthesis (SPPS), microwave irradiation, procedures on Rink Amide resin (substitution $0.5 \mathrm{mmol} / \mathrm{g}$, $25 \mu \mathrm{mol}$ ) in SPE polypropylene Single-Fritted tubes. The Fmocprotecting group was then removed by treating the resin with $20 \%$ (v/v) piperidine diluted in dimethylformamide (DMF) followed by heating to $80^{\circ} \mathrm{C}$ in the microwave (MARS, CEM, United States; 2 -min ramp to $80^{\circ} \mathrm{C}, 2$-min hold at $80^{\circ} \mathrm{C}$ ) with stirring. To couple each amino-acid, Fmoc-protected amino acids (4 equiv. relative to the overall loading of the resin), were dissolved in DMF and mixed with 2-(1H-benzotriazol1-yl)-1,1,3,3-tetramethyluronium hexafluorophosphate (HBTU; 4 equiv.) and diisopropylethylamine (DIEA; 4 equiv.). The solution was allowed to pre-activate for $5 \mathrm{~min}$ before being added to the resin, and heated to $70^{\circ} \mathrm{C}$ in a multimode microwave (2-min ramp to $70^{\circ} \mathrm{C}, 4$-min hold at $70^{\circ} \mathrm{C}$ ) with stirring. After each coupling/deprotection cycle the resin was drained and washed with DMF $(3 \times 5 \mathrm{~mL})$. Once peptide synthesis was completed, the peptide was cleaved from the resin, by mixing the resin with $3 \mathrm{~mL}$ cleavage cocktail of 95\% trifluoroacetic acid (TFA), 2.5\% triisopropylsilane (TIPS), and $2.5 \%$ deionized water for $3 \mathrm{~h}$ with agitation. The peptide mixture was precipitated from the TFA solution by the addition of cold ether and collected by centrifugation (Eppendorf R5810 $8000 \mathrm{rpm}$ for $10 \mathrm{~min}$ ). The ether was then removed, and the peptide was dried under a stream of nitrogen, and lyophilized, before high-performance liquid chromatography (HPLC) purification.

\section{Peptide Purification}

Crude peptides were purified and characterized with ReversePhase (RP)-HPLC. The crude peptides were diluted to a final concentration of $10 \mathrm{mg} / \mathrm{ml}$ in a solution of $20 \%$ acetonitrile $(\mathrm{ACN})$ in water (v/v) or dimethyl sulfoxide (DMSO). A semipreparative Phenomenex Kinetex C18 (5 $\mathrm{m}, 10 \times 250 \mathrm{~mm}$ ) was used for preparative RP-HPLC work. An analytical Phenomenex Gemini C18 column (5 $\mu \mathrm{m}, 4.6 \mathrm{~mm} \times 250 \mathrm{~mm}, 110$ A) was used for analytical RP-HPLC work (Supplementary Figure S1). Standard RP-HPLC conditions were as follows:

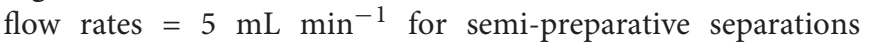
and $1 \mathrm{~mL} \min ^{-1}$ for analytical separations; mobile phase $A=18 \mathrm{M} \Omega$ water $+0.1 \%$ TFA; mobile phase $B=\mathrm{ACN}$. Purities were determined by integration of peaks with UV detection at $220 \mathrm{~nm}$ using a linear gradient (first prep 5\% $\mathrm{B} \rightarrow 65 \% \mathrm{~B}$ over $60 \mathrm{~min}$ and second prep $26 \% \mathrm{~B} \rightarrow$ $36 \% \mathrm{~B}$ over $20 \mathrm{~min})$. The purity of the tested peptides was determined using a linear gradient $(5 \% \mathrm{~B} \rightarrow 65 \% \mathrm{~B}$ 
over $60 \mathrm{~min}$ ). MALDI-TOF spectrometry (Bruker Daltonik, Germany) was used to validate the synthesized peptides molecular weight (Supplementary Table S1). The purified peptides were lyophilized and stored at $-20^{\circ} \mathrm{C}$.

\section{Analysis of PIcR Regulon Expression Using $\beta$-Galactosidase Assay PIcR Activation Studies}

Bt $\triangle$ papR A'Z cells were grown overnight in LB medium with selective antibiotic. The cells were diluted $10^{-3}$ in modified LB to a final volume of 1 liter and incubated at $37^{\circ} \mathrm{C}$ with shaking (200 rpm) until onset of the stationary phase of bacterial growth $\left(\mathrm{OD}_{600} 3 \pm 0.5\right)$. Various concentrations of synthetic peptides were added to $2 \mathrm{ml}$ aliquots of culture, which were incubated for $1 \mathrm{~h}$ before centrifugation (Eppendorf centrifuge R5810, $4000 \mathrm{rpm}$ for $5 \mathrm{~min}$ ) and quantification of $\beta$-galactosidase.

\section{Competition Studies of $\mathrm{PapR}_{7}$-Derived Peptides}

Bt A'Z cells were grown overnight in LB medium. The cells were diluted $10^{-3}$ in modified LB to a final volume of $1 \mathrm{~L}$ and incubated at $37^{\circ} \mathrm{C}$ with shaking $(200 \mathrm{rpm})$ until the end of the lag or late-exponential of bacterial growth $\left(\mathrm{OD}_{600} 0.1 \pm 0.03\right.$; $1.8 \pm 0.1$, respectively). Different concentrations of synthetic peptides were added to $2 \mathrm{ml}$ aliquots of culture and incubated for various times $(1-24 \mathrm{~h})$ before centrifugation (Eppendorf centrifuge R5810, $4000 \mathrm{rpm}$ for $5 \mathrm{~min}$ ) and quantification of $\beta$-galactosidase activity.

\section{$\beta$-Galactosidase Assay}

$\beta$-galactosidase activity was measured as described previously (Yang et al., 2017), with minor modifications. Briefly, $200 \mu \mathrm{L}$ aliquots from $2 \mathrm{ml}$ treated cultures were added in triplicate to a clear 96-well microtiter plate, and then $\mathrm{OD}_{600}$ was measured and $\beta$-galactosidase activity was assayed. The final results were reported as percentage of activation, which is the ratio between the Miller units obtained after addition of the $\mathrm{PapR}_{7}$ analogs. In Bt $\triangle$ papR A'Z strain, the plcA promoter activity was very low and considered as a baseline. In $\mathrm{Bt} \mathrm{A}^{\prime} \mathrm{Z}$ strain, the untreated bacteria were considered as $100 \%$ of activation and the results were normalized accordingly. Each assay was repeated at least three times.

\section{Hemolytic Assay Toward Human Red Blood Cells}

Bt A'Z or B. cereus ATCC 14579 cells were grown overnight in LB medium. The cells were diluted $10^{-3}$ in modified LB to a final volume of 1 liter and incubated at $37^{\circ} \mathrm{C}$ with shaking $(200 \mathrm{rpm})$ until the end of the lag phase of bacterial growth $\left(\mathrm{OD}_{600} 0.1 \pm 0.03\right)$. Different concentrations of synthetic peptides were added to $2 \mathrm{ml}$ aliquots of culture and incubated for $2.5 \mathrm{~h}$ before centrifugation (Eppendorf centrifuge R5810, $4000 \mathrm{rpm}$ for $5 \mathrm{~min})$, separation and filtration $(0.2 \mu \mathrm{m}$ filter $)$ of the supernatants of the treated cultures. Analyses of hemolytic activity were conducted as previously described using human red blood cells (Tal-Gan et al., 2013b; Lobel et al., 2015). Bacterial supernatants were serially diluted in Tris-buffered saline $(\mathrm{pH}$
7.2, $10 \mathrm{mM}$ Tris- $\mathrm{HCl}, 155 \mathrm{mM} \mathrm{NaCl}$ ) with $1 \%$ human red blood cells (hRBC) suspension and were incubated for $30 \mathrm{~min}$ at $37^{\circ} \mathrm{C}$. Hemolytic activities were measured by monitoring the absorbance at $420 \mathrm{~nm}$.

\section{Statistical Analysis}

Unless otherwise noted, the results are presented as the mean \pm SEM. One-way analysis ANOVA of variance, followed by Tukey post hoc analysis was used for statistical analysis. The results were considered to be statistically significant if $p<0.01$.

\section{RESULTS}

We have previously reported the first five synthetic peptidic inhibitors of B. cereus PlcR-PapR QS system; three independent alanine amino acid replacements $\left(\mathrm{PapR}_{7}-\mathrm{P} 4 \mathrm{~A}, \mathrm{E} 6 \mathrm{~A}\right.$, and F7A) and two D-amino acid substitutions $\left(\mathrm{PapR}_{7}-\mathrm{dE}_{6}\right.$ and $\left.\mathrm{dF}_{7}\right)$ showed great reduction of $\mathrm{PlcR}$ regulon expression and virulence factor secretion (Yehuda et al., 2018).

We initiated the current study by evaluating the three crucial positions of the heptapeptide PapR -proline (Pro4), glutamic acid (Glu6) and phenylalanine (Phe7) through systematic single or/and multiple amino acid substitution strategy. We designed, synthesized and purified a second generation set of $\mathrm{PapR}_{7}$ derived peptide combinations to further explore the structureactivity relationship delineated previously for the first-generation of peptidic analogs. This set included twelve peptides with double and triple alanine and D-amino acid replacements, at the crucial Pro4, Glu6 and Phe7 residues (Supplementary Table S1, Supplementary Figure S1 and Figure 1).

We scanned each of $\mathrm{PapR}_{7}$-derived peptide combinations for its ability to modulate the expression of the PlcR regulon using B. thuringiensis $407 \mathrm{Cry}^{-}\left(\mathrm{Bt} 407^{-}\right)$as a model bacterium for the B. cereus group. This strain cured of its plasmid is acrystalliferous and shows high phylogenic similarity with the $B$. cereus reference strain ATCC 14579 (Lereclus et al., 1989; Priest et al., 1994; Slamti and Lereclus, 2005). Two lacZ-based reporter strains were used in the current study, B. thuringiensis $407^{-}$plc $A^{\prime} Z$ (Bt A'Z) and PapRnull mutant $B$. thuringiensis $407^{-} \Delta$ papR $p l c A^{\prime} Z$ (Bt $\Delta$ papR A'Z). Both reporter strains contain a transcriptional fusion between the $p l c A$ promoter region and the $l a c Z$ gene. $p l c A$ is a member of the PlcR regulon and its expression directly reflects the activity of PlcR. The activity of each $\mathrm{PapR}_{7}$-derived peptide combination was evaluated and compared to the previously described five B. cereus inhibitory synthetics $\mathrm{PapR}_{7}$-derived peptides $\left(\mathrm{PapR}_{7}-\right.$ P4A; E6A; F7A; $\mathrm{dE}_{6}$ and $\mathrm{dF}_{7}$; Yehuda et al., 2018).

We first conducted an initial screening of all the analogs at high peptide concentration $(5 \mu \mathrm{M})$ in order to evaluate their ability to activate the PlcR regulon to a level comparable to the synthetic PapR 7 signal peptide (Figure 2). Both first and second generations of $\mathrm{PapR}_{7}$ analogous were classified by their number of amino acid replacements (alanine or D-amino); single, double and triple. Similar to our first-generation single replacement inhibitors, none of the new $\mathrm{PapR}_{7}$-derived peptide combinations were capable of activating the PlcR regulon. These findings revealed that any alanine and D-amino acid replacements, at the 


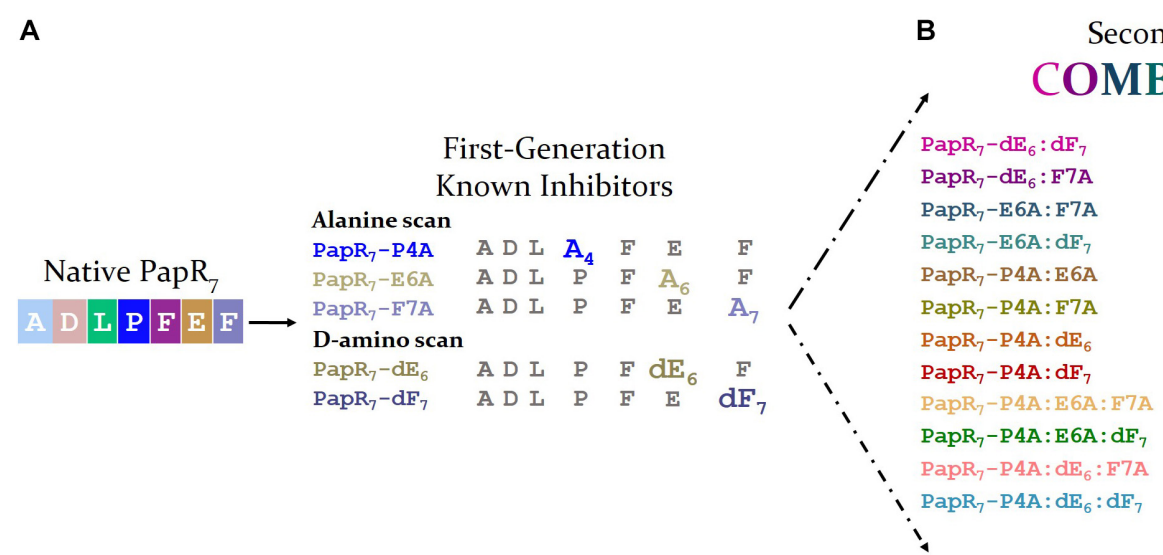

Second-Generation

$\begin{array}{llllll}\mathrm{A} & \mathrm{L} & \mathrm{P} & \mathrm{F} & \mathrm{dE} & \mathrm{dF}_{7}\end{array}$

$\begin{array}{lllllll}A & D & P & F & d^{6} & A_{7}\end{array}$

$\begin{array}{llllll}\mathrm{A} & \mathrm{I} & \mathrm{P} & \mathrm{F} & \mathrm{A}_{6} & \mathrm{~A}_{7}\end{array}$

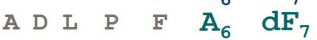

$\begin{array}{llllllll}\mathrm{A} & \mathrm{D} & \mathrm{A}_{4} & \mathrm{~F} & \mathrm{~A}_{6} & \mathrm{~F}\end{array}$

$\begin{array}{llllll}\mathrm{A} & \mathrm{I} & \mathrm{A}_{4} & \mathrm{~F} & \mathrm{E} & \mathrm{A}_{7}\end{array}$

$\begin{array}{llllllll}A & D & A_{4} & F & d E_{6} & F\end{array}$

$\mathrm{A} D \mathrm{I}_{4} \mathrm{~A}_{4} \quad \mathrm{~F} \quad \mathrm{E} \quad \mathrm{dF}_{7}$

A D I $\begin{array}{lllll}\mathrm{A}_{4} & \mathrm{~F} & \mathrm{~A}_{6} & \mathrm{~A}_{7}\end{array}$

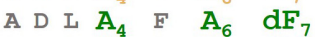

$\begin{array}{llllllll}\mathrm{A} & \mathrm{D} & \mathrm{A}_{4} & \mathrm{~F} & \mathrm{dE}_{6} & \mathrm{~A}_{7}\end{array}$

$\begin{array}{llllllll}\mathrm{A} & \mathrm{D} & \mathrm{L} & \mathrm{A}_{4} & \mathrm{~F} & \mathrm{dE}_{6} & \mathrm{dF}_{7}\end{array}$

FIGURE 1 | Second generation of PapR 7 -derived peptide combinations. (A) Sequences of first generation potent synthetic inhibitors 7-mer PapR-derived peptides (PapR7; ADLPFEF) involved D-amino acid or alanine replacements at three positions; proline (P) glutamic (E), and phenylalanine (F) of the heptapeptide PapR. (B) Sequences of second generation of $\mathrm{PapR}_{7}$-derived peptide combinations, involved double and triple alanine and $\mathrm{D}$-amino acids replacement.

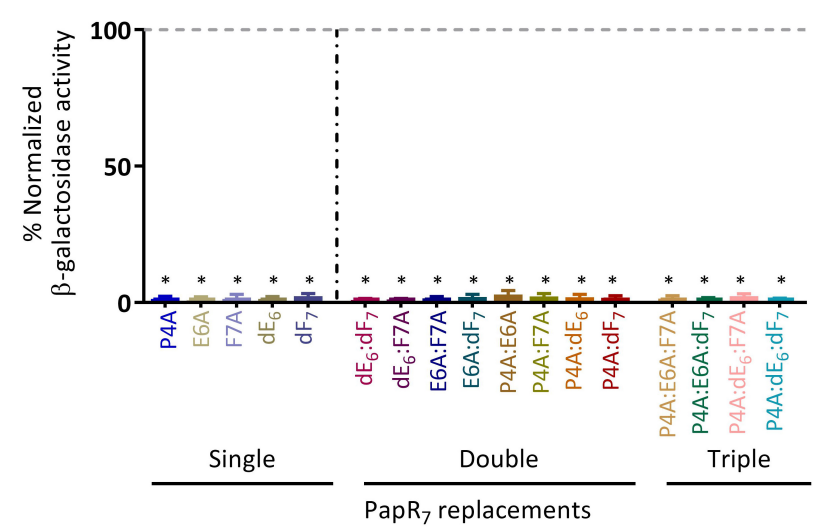

FIGURE 2 | PlcR regulon activation by the new $\mathrm{PapR}_{7}$-derived peptide combinations. $\beta$-galactosidase activity of Bt $\Delta$ papR A'Z induced by the addition of $5 \mu \mathrm{M} \mathrm{PapR}_{7}$-derived peptides normalized to synthetic $\mathrm{PapR}_{7}$ signal peptide at onset of the stationary phase of bacterial growth $\left(\mathrm{OD}_{600}\right.$ of $3 \pm 0.5$, mean \pm SEM, $n=9$ ). ${ }^{*} p<0.01$ indicates a statistically significant difference between addition of synthetic $\mathrm{PapR}_{7}$ peptide and $\mathrm{PapR}_{7}$ derived peptides.

positions Pro4, Glu6 and Phe7 of $\mathrm{PapR}_{7}$ derivatives, are critical for $\mathrm{PlcR}$ regulon activation. These derivatives can therefore be classified as potential candidates for the development of potent second-generation PlcR inhibitors.

We next scrutinized their ability to compete with the endogenous PapR signal peptide (in Bt A'Z reporter strain) for reducing the activation of the $\mathrm{PlcR}$ regulon in late-exponential phase of bacterial growth $\left(\mathrm{OD}_{600}\right.$ of $\left.1.8 \pm 0.1\right)$. As shown in Figure 3A; $\mathrm{PapR}_{7}$ derivatives activities were classified by D-amino acid enantiomer or Ala replacements at either of the three $\mathrm{PapR}_{7}$ crucial positions (Pro4, Glu6 and Phe7). The previously reported inhibitors, $\mathrm{PapR}_{7}-\mathrm{P} 4 \mathrm{~A}$; E6A; F7A; $\mathrm{dE}_{6}$ and $\mathrm{dF}_{7}$, were also included for comparison. Peptides $\mathrm{PapR}_{7}$ - P4A:E6A, P4A:E6A:F7A and P4A:E6A:dF 7 did not show any reduction in plcA'Z activity. $\mathrm{PapR}_{7}$ - E6A:F7A, E6A:dF $7, P 4 A: F 7 A, P 4 A: \mathrm{dE}_{6}, \mathrm{P} 4 \mathrm{~A}: \mathrm{dF}_{7}, \mathrm{PapR}_{7}-\mathrm{P} 4 \mathrm{~A}: \mathrm{dE}_{6}: \mathrm{dF}_{7}$ and $\mathrm{P} 4 \mathrm{~A}: \mathrm{dE}_{6}: \mathrm{F} 7 \mathrm{~A}$ were able to reduce $p l c A^{\prime} Z$ activity by approximately $40 \%$. We identified two candidate peptides that inhibited $p l c A^{\prime} Z$ activation when added at late-exponential phase. Indeed, $\mathrm{PapR}_{7}-\mathrm{dE}_{6}: \mathrm{dF}_{7}$ and $\mathrm{dE}_{6}: \mathrm{F} 7 \mathrm{~A}$ reduced $p l c A^{\prime} Z$ activity by 71 and $65 \%$, respectively, similarly to the inhibitory activity of their parent reporter inhibitors $\mathrm{PapR}_{7}-\mathrm{dE}_{6}, \mathrm{dF}_{7}$ and F7A (65, 63, and 70\%, respectively). To confirm $\mathrm{PapR}_{7}-\mathrm{dE}_{6}: \mathrm{dF}_{7}$ and $\mathrm{dE}_{6}$ :F7A potent inhibition, we repeated the experiment with several concentrations of these inhibitors in order to determine their $\mathrm{IC}_{50}$ values (Figures $3 \mathrm{~B}, \mathrm{C}$ ). The results show that the new inhibitory peptides have $\mathrm{IC}_{50}$ values in the low micromolar range, almost comparable to their parent reporter inhibitors $\mathrm{IC}_{50}$ values (Table 1). Overall, we identified new potent inhibitors, $\mathrm{PapR}_{7}-\mathrm{dE}_{6}: \mathrm{dF}_{7}$ and $\mathrm{dE}_{6}: \mathrm{F} 7 \mathrm{~A}$, which were able to compete with endogenous PapR and inhibit PlcR regulon activity very effectively. Interestingly, these two potent inhibitors contain D-Glutamic acid replacement at position 6 of the PapR heptapeptide.

We have previously reported that inhibition through $\mathrm{PapR}_{7}$ inhibitory peptidic derivatives is cell density dependent (Slamti and Lereclus, 2002; Yehuda et al., 2018). To examine the effect of bacterial cell density on the inhibition of the PlcR regulon expression, each derivative was added to $\mathrm{Bt} \mathrm{A}^{\prime} \mathrm{Z}$ cells at $\mathrm{OD}_{600}$ $0.1 \pm 0.03$, which corresponds to the early stage of exponential phase. PlcR-dependent gene expression was then quantified after $2.5 \mathrm{~h}$ (Figure 4) and after $24 \mathrm{~h}$ in order to assess their activity and stability over time (Supplementary Figure S2). As has been reported recently, all of our known parent $\mathrm{PapR}_{7}$ inhibitors were able to completely block plcA'Z activation for up to $24 \mathrm{~h}$ under these conditions (Yehuda et al., 2018). We observed similar results with $\mathrm{PapR}_{7}-\mathrm{dE}_{6}: \mathrm{dF}_{7}$ and $\mathrm{dE}_{6}: \mathrm{F} 7 \mathrm{~A}$; these peptides blocked plcA'Z activation compared to the parent peptidic inhibitors for $2.5 \mathrm{~h}$ and up to $24 \mathrm{~h}$ (Figure 4 and Supplementary Figure S2). Combining them with additional alanine replacement at Pro4, $\mathrm{PapR}_{7}-\mathrm{P} 4 \mathrm{~A}: \mathrm{dE}_{6}: \mathrm{dF}_{7}$ and $\mathrm{P} 4 \mathrm{~A}: \mathrm{dE}_{6}:$ F7A showed a 

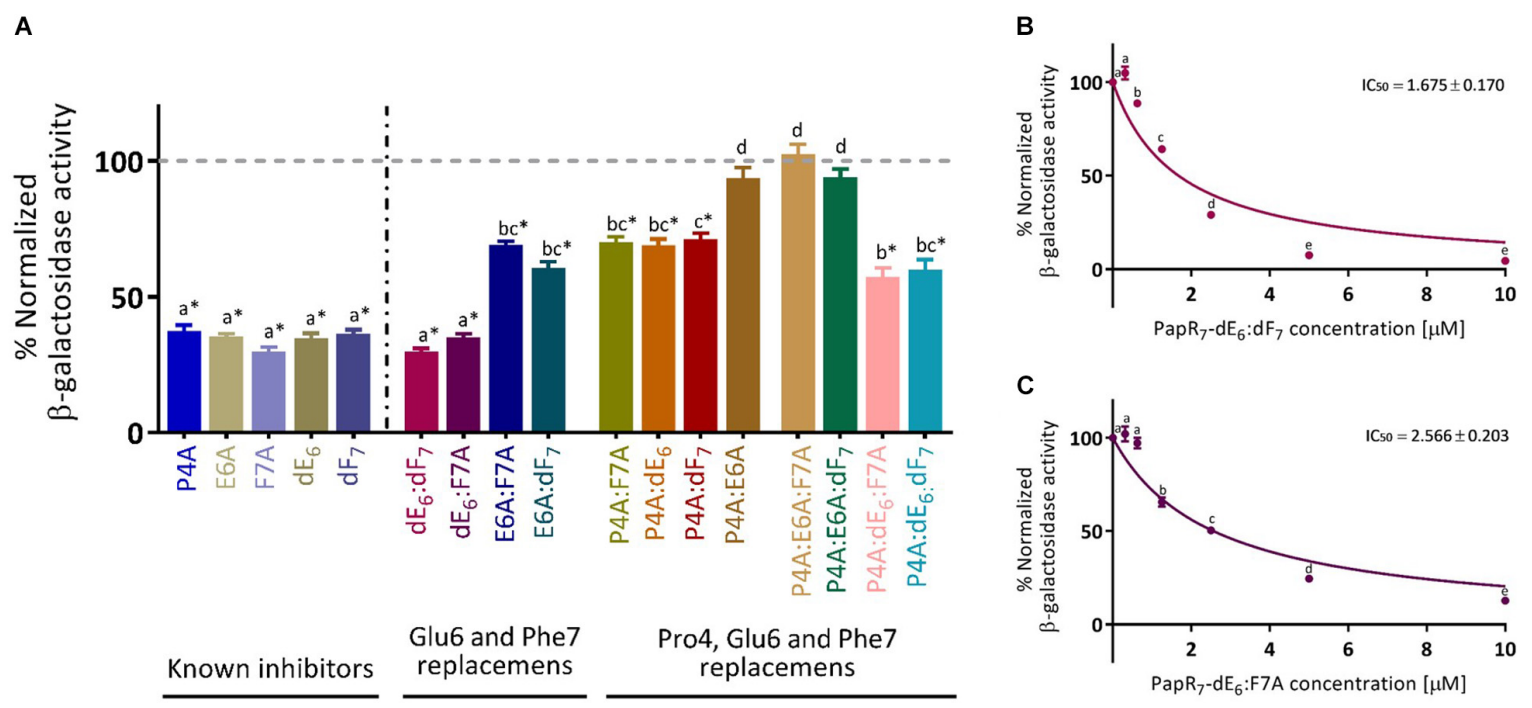

FIGURE 3 | Competition studies with new PapR 7 -derived peptide combinations. (A) $\beta$-galactosidase activity of Bt $A^{\prime} Z$ induced by the addition of $2.5 \mu M$ $\mathrm{PapR}_{7}$-derived peptides, (B) PapR $-\mathrm{dE}_{6}: \mathrm{dF}_{7}$, and (C) $\mathrm{PapR}_{7}-\mathrm{dE}_{6}: F 7 A$ derivatives in several concentrations normalized to untreated bacterial cells at late-exponential of bacterial growth (OD 600 of $1.8 \pm 0.1$, mean $\pm \mathrm{SEM}, n=9)$. ${ }^{*} p<0.01$ indicates a statistically significant difference between untreated Bt $A^{\prime} Z$ and addition of PapR $\mathrm{P}_{7}$-derived peptides. Different letters indicate statistically significant differences between PapR $\mathrm{R}_{7}$-derived peptide treatments $(p<0.01)$.

reduction of $\sim 75 \%$ in plcA'Z activation. The addition of $\mathrm{PapR}_{7}$ derivatives as $\mathrm{PapR}_{7}-\mathrm{E} 6 \mathrm{~A}: \mathrm{F} 7 \mathrm{~A}, \mathrm{E} 6 \mathrm{~A}: \mathrm{dF}_{7}, \mathrm{P} 4 \mathrm{~A}: \mathrm{F} 7 \mathrm{~A}, \mathrm{P} 4 \mathrm{~A}: \mathrm{dE}_{6}$ and $\mathrm{P} 4 \mathrm{~A}: \mathrm{dF}_{7}$ in the early stages of the bacterial growth led to drastic reduction in $p l c A^{\prime} Z$ activity, revealing a series of new peptidic inhibitors. In contrast, the non-inhibitory peptidic combinations (PapR 7 - P4A:E6A, P4A:E6A:F7A and P4A:E6A:dF $)$ did not reduce the $\mathrm{PlcR}$ regulon expression even in low bacterial density. Importantly, the bacterial growth was not affected by the addition of all the examined peptides (data not shown).

Throughout these competition studies, we identified a group of three non-inhibitory peptidic combinations (PapR $-\mathrm{P} 4 \mathrm{~A}: \mathrm{E} 6 \mathrm{~A}$, P4A:E6A:F7A and P4A:E6A: $\mathrm{dF}_{7}$ ), seven variants of $\mathrm{PapR}_{7}$ containing multiple replacements combinations with median to high inhibitory activities $\left(\mathrm{PapR}_{7}-\mathrm{P} 4 \mathrm{~A}: \mathrm{dE}_{6}: \mathrm{F} 7 \mathrm{~A}, \mathrm{P} 4 \mathrm{~A}: \mathrm{dE}_{6}: \mathrm{dF}_{7}\right.$, E6A:F7A, E6A: $\mathrm{dF}_{7}, \mathrm{P} 4 \mathrm{~A}: \mathrm{F7A}, \mathrm{P} 4 \mathrm{~A}: \mathrm{dE}_{6}$ and $\left.\mathrm{P} 4 \mathrm{~A}: \mathrm{dF}_{7}\right)$ and two very potent inhibitors that abolish activation of plcA'lacZ $\left(\mathrm{PapR}_{7}\right.$ - $\mathrm{dE}_{6}: \mathrm{dF}_{7}$ and $\left.\mathrm{dE}_{6}: \mathrm{F} 7 \mathrm{~A}\right)$ and compete with endogenous PapR. These two peptides are proposed as quorum quenchers that

TABLE 1 | Comparison between $\mathrm{IC}_{50}$ values of new $\mathrm{PapR}_{7}$-derived peptide combinations and their parent inhibitors, as determined by the lacZ-based reporter assay.

\begin{tabular}{|c|c|c|c|}
\hline \multicolumn{4}{|c|}{$\mathrm{Ic}_{50}[\mu \mathrm{M}]^{*}$} \\
\hline $\mathrm{PapR}_{7}-\mathrm{dE}_{6}: \mathrm{dF}_{7}$ & $1.675 \pm 0.170^{a}$ & $\mathrm{PapR}_{7}-\mathrm{dE}_{6}$ & $0.977 \pm 0.042^{\mathrm{C}}$ \\
\hline $\mathrm{PapR}_{7}-\mathrm{dE}_{6}: \mathrm{F} 7 \mathrm{~A}$ & $2.566 \pm 0.203^{b}$ & $\mathrm{PapR}_{7}-\mathrm{dF}_{7}$ & $1.223 \pm 0.072^{\mathrm{ac}}$ \\
\hline & & $\mathrm{PapR}_{7}-\mathrm{F} 7 \mathrm{~A}$ & $1.675 \pm 0.102^{a}$ \\
\hline
\end{tabular}

* $/ C_{50}$ values were calculated by GraphPad Prism 8, using the non-linear inhibitor vs. normalized response method. Different letters indicate statistically significant differences between $I C_{50}$ values of Pap $R_{7}$-derived peptide combinations $(p<0.01)$.

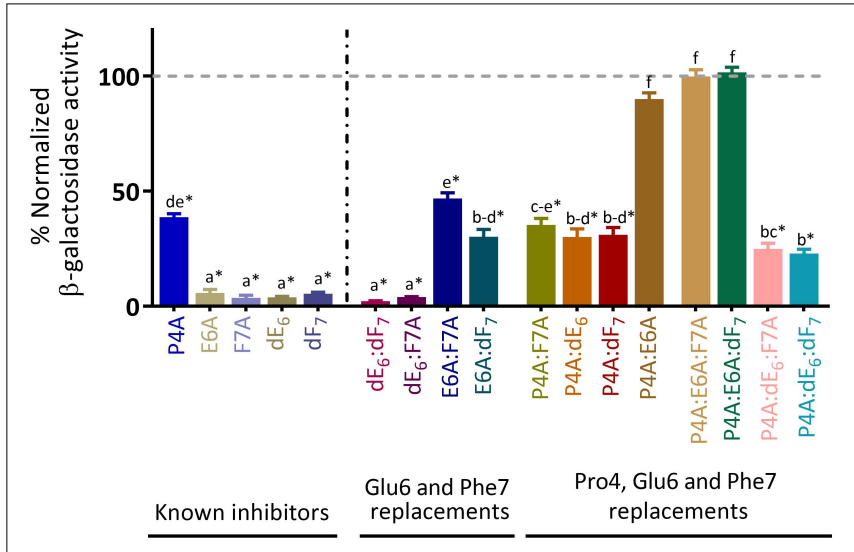

FIGURE 4 | Exploring the effect of bacterial cell density on the $\mathrm{PapR}_{7}$-derived peptide combinations activity. $\beta$-galactosidase activity of $\mathrm{Bt} A$ ' $Z$ induced by the addition of $10 \mu \mathrm{M} \mathrm{PapR}$-derived peptides normalized to untreated bacterial cells at end lag phase of bacterial growth $\left(\mathrm{OD}_{600}\right.$ of $0.1 \pm 0.03$; mean \pm SEM, $n=9$ ). ${ }^{*} p<0.01$ indicates a statistically significant difference between untreated $B t A^{\prime} Z$ and addition of $P_{a p R}$-derived peptides. Different letters indicate statistically significant differences between $\mathrm{PapR}_{7}$-derived peptide treatments $(p<0.01)$.

do not affect the bacterial growth but inhibit the expression of the $\mathrm{PlcR}$ regulon.

After observing this inhibitory activity, we expanded our study to explore the effect of these second generation $\mathrm{PapR}_{7}$ analogs on the production of a representative virulence factor under the control of PlcR in wild-type bacteria. Previous studies have shown that the activity of hemolysins in B. cereus is regulated by the PlcR - PapR QS system (Salamitou et al., 2000; Slamti and Lereclus, 2002; Slamti et al., 2004). Therefore, we studied 
the effect of the new $\mathrm{PapR}_{7}$ derivatives on the production of hemolysins in $B$. cereus strain ATCC 14579, a representative member of the $B$. cereus sensu stricto species.

We performed hemolytic activity assays toward human red blood cells in the presence of the synthetic derivatives (Figure 5A). From these results, we identified $\mathrm{PapR}_{7}$ inhibitory peptidic analogs that were able to reduce the hemolytic activity of wild type $B$. cereus ATCC 14579. Interestingly, these analogs reduced the expression of hemolysin (Figure 5A) even more efficiently than the inhibition that was observed for Bt $407^{-}$ PlcR-dependent gene expression (as shown in Figure 4). We quantified the hemolytic activity of the strong inhibitors group by determining their $\mathrm{IC}_{50}$ values. In addition to the two strong inhibitors derivatives $\left(\mathrm{PapR}_{7}-\mathrm{dE}_{6}: \mathrm{dF}_{7}, \mathrm{dE}_{6}: \mathrm{F} 7 \mathrm{~A}\right)$, we observed great activity also for $\mathrm{PapR}_{7}-\mathrm{P} 4 \mathrm{~A}: \mathrm{dE}_{6}: \mathrm{dF}_{7}$ and $\mathrm{P} 4 \mathrm{~A}: \mathrm{dE}_{6}: F 7 \mathrm{~A}$ analogs. Regard to $\mathrm{PapR}_{7}-\mathrm{dE}_{6}: \mathrm{dF}_{7}$ and $\mathrm{dE}_{6}: \mathrm{F} 7 \mathrm{~A}$ derivatives, the relative $\mathrm{IC}_{50}$ value trends were highly similar to those in the lacZ-reporter assays results (Figure 5B and Tables 1, 2). In comparison to their parent single inhibitors $\mathrm{PapR}_{7}-\mathrm{dF}_{7}$ and $\mathrm{F} 7 \mathrm{~A}$, the relative $\mathrm{IC}_{50}$ values were in the same range (Figures 5B,C and Table 2); addition of D- Glutamic acid in the parent peptide $\mathrm{PapR}_{7}-\mathrm{dF}_{7}\left(\mathrm{PapR}_{7}-\mathrm{dE}_{6}: \mathrm{dF}_{7}\right)$ slightly improved its $\mathrm{IC}_{50}$ ( $\mathrm{IC}_{50}$ value was reduced to 1.382 compared to 3.041 ), while alanine substituted at position Phe7 $\left(\mathrm{PapR}_{7}-\right.$ $\left.\mathrm{dE}_{6}: \mathrm{F} 7 \mathrm{~A}\right)$ did not show any effect. PapR $_{7}-\mathrm{P} 4 \mathrm{~A}: \mathrm{dE6}$ :dF7 and P4A:dE6:F7A exhibited lower $\mathrm{IC}_{50}$ values compared to their parent single inhibitors $\mathrm{PapR}_{7}-\mathrm{P} 4 \mathrm{~A}, \mathrm{dF}_{7}$ and $\mathrm{F} 7 \mathrm{~A}$ but a higher $\mathrm{IC}_{50}$ value compared to the parent peptide $\mathrm{PapR}_{7}-$ $\mathrm{dE}_{6}$ (Table 2). We observed another key feature in the new $\mathrm{PapR}_{7}$ combinations; sharing specific substitutions at $\mathrm{PapR}_{7}$ sequence influence their ability to inhibit PlcR activity; for example, all non-inhibitory peptidic combinations included alanine substitutions at positions Pro4 and Glu6 of $\mathrm{PapR}_{7}$ peptide, while all strong inhibitors group members share replacement of Glu6 by its D-isomer. All these new PapR 7 combinations activity profiles may shed light on PlcR and PapR interaction. To better understand their role in PlcR activity, we divided the delineated above (Figure 5) $\mathrm{PapR}_{7}$-derived peptidic combinations hemolytic activities on human red blood cells to three different sets (Figures 6A-C).

TABLE 2 | Comparison between $\mathrm{IC}_{50}$ values of new $\mathrm{PapR}_{7}$-derived peptide combinations and their parent inhibitors, as determined by the hemolytic assay.

\begin{tabular}{|c|c|c|c|}
\hline \multicolumn{4}{|c|}{ IC. 50 values $[\mu \mathrm{M}]^{*}$} \\
\hline $\mathrm{PapR}_{7}-\mathrm{dE}_{6}: \mathrm{dF}_{7}$ & $1.382 \pm 0.117^{\mathrm{ab}}$ & $\mathrm{PapR}_{7}-\mathrm{dE}_{6}$ & $1.053 \pm 0.089^{a}$ \\
\hline \multirow{2}{*}{$\mathrm{PapR}_{7}-\mathrm{dE}_{6}: \mathrm{F} 7 \mathrm{~A}$} & $2.497 \pm 0.212^{\mathrm{cd}}$ & $\mathrm{PapR}_{7}-\mathrm{dF}_{7}$ & $3.041 \pm 0.206^{\mathrm{cd}}$ \\
\hline & & $\mathrm{PapR}_{7}-\mathrm{F} 7 \mathrm{~A}$ & $2.725 \pm 0.239^{d}$ \\
\hline$P_{a p R}-P 4 A: d_{6}: d_{7}$ & $2.141 \pm 0.148^{b-d}$ & $\mathrm{PapR}_{7}-\mathrm{P} 4 \mathrm{~A}$ & $4.391 \pm 0.288^{\mathrm{e}}$ \\
\hline \multirow[t]{3}{*}{ PapR7-P4A: dE 6 : F7A } & $1.994 \pm 0.184^{a-c}$ & $\mathrm{PapR}_{7}-\mathrm{dE}_{6}$ & $1.053 \pm 0.089^{a}$ \\
\hline & & $\mathrm{PapR}_{7}-\mathrm{dF}_{7}$ & $3.041 \pm 0.206^{\mathrm{cd}}$ \\
\hline & & $\mathrm{PapR}_{7}-\mathrm{F} 7 \mathrm{~A}$ & $2.725 \pm 0.239^{d}$ \\
\hline
\end{tabular}

${ }^{*}{ } C_{50}$ values were calculated by GraphPad Prism 8, using the nonlinear inhibitor vs. normalized response method. Different letters indicate statistically significant differences between $I C_{50}$ values of PapR $R_{7}$-derived peptide combinations $(p<0.01)$.

\section{SUMMARY}

\section{Role of Individual and Combined Pro4 or Glu6 Residue Replacements}

Replacing both Pro4 and Glu6 in $\mathrm{PapR}_{7}$ with alanine yielded nonactive peptidic combinations regardless of other modifications in Phe7 position (PapR $_{7-}$ P4A:E6A, P4A:E6A:F7A, and P4A:E6A:dF 7 ; Figure 6A). PapR 7 - P4A:E6A:F7A and P4A:E6A are non-inhibitory peptides, while $\mathrm{PapR}_{7}-$ E6A:F7A and P4A:F7A defined as medium inhibitors, reduce the hemolytic activity by $\sim 60 \%$. The same trend was observed with other two non-inhibitory peptidic combinations; $\mathrm{PapR}_{7}$ - P4A:E6A: $\mathrm{dF}_{7}$ and PapR $_{7}$ - P4A:E6A compared to their disassembled peptidic combinations PapR - E6A:dF 7, P4A: $\mathrm{dF}_{7}$ and $\mathrm{PapR}_{7}-\mathbf{P 4 A}, \mathbf{E 6 A}$, respectively. These findings verified the dependence of proline and glutamic acid residues in $\mathrm{PapR}_{7}$ inhibitory activity. By modifying these two residues together to alanine the $\mathrm{PapR}_{7}$ derived inhibitors lost their antagonist features and their ability to prevent native PapR-PlcR interaction. This is in agreement with previous study (Bouillaut et al., 2008; Grenha et al., 2013), which emphasizes that both proline and glutamic acid have an important role in $\mathrm{PlcR}$ activation.

\section{Effect of Phe7 Replacement}

Crystal structure of $\mathrm{PapR}_{7}-\mathrm{PlcR}$ complex showed that both $\mathrm{PapR}_{7}$ phenylalanine residues (Positions 5 and 7) are located in hydrophobic pockets (Grenha et al., 2013), and involved in hydrophobic interactions with PlcR. We examined the effect of replacing Phe7 with alanine or D-amino acid on the inhibitory activities of the designed peptides. Introducing D-Phenylalanine at position 7 , regardless to the modifications at position 4 and 6, enhances the inhibitory activity of PlcR (Figure 6B). Replacing F7 in alanine $\left(\mathrm{PapR}_{7}-\mathrm{E} 6 \mathrm{~A}: \mathrm{F7A}\right.$ or P4A:F7A) reduced hemolysis of red blood cells by $60 \%$. However, these replacements combined with D-Phenylalanine yielded analogs $\left(\mathrm{PapR}_{7}-\right.$ $\mathrm{E} 6 \mathrm{~A}: \mathbf{d F}_{7}$ and $\mathrm{P} 4 \mathrm{~A}: \mathbf{d F}_{7}$ ) with stronger antagonistic activities (approximately $83 \%$ inhibition). These results indicate that the inclusion of $\mathrm{D}$-Phenylalanine may contribute to hydrophobic interactions with $\mathrm{PlcR}$ by preserving the aromatic ring side chain interaction.

\section{Importance of Glu6 and Its Stereoisomer Substitution}

We observed that all the strong inhibitor group members contain the replacement of Glu6 to its D-enantiomer (Figure 5A). PapR $_{7}-\mathbf{d E}_{6}:$ F7A and $\mathbf{d E}_{6}: \mathrm{dF}_{7}$ displayed similar inhibitory effect, regardless of other modifications (D-amino or alanine replacements) in position Phe7 (Figure 6C). In contrast, replacing Glu6 with alanine yielded two weaker $\mathrm{PlcR}$ antagonists, when either Phe7 combined substitutions with alanine or D-amino $\left(\mathrm{PapR}_{7}\right.$ - E6A:F7A and E6A:dF 7$)$. PapR - P4A: $\mathrm{dE}_{6}: \mathrm{F} 7 \mathrm{~A}$ and $\mathrm{P} 4 \mathrm{~A}: \mathrm{dE}_{6}: \mathrm{dF}_{7}$ fully prevented hemolysis of red blood cells, however, replacing only Glu6 with alanine yielded two non-inhibitory peptidic combinations $\mathrm{PapR}_{7}$ P4A:E6A:F7A and P4A:E6A: $\mathrm{dF}_{7}$ as was supported by $\mathrm{IC}_{50}$ values (Figure 6D). 


\section{A}

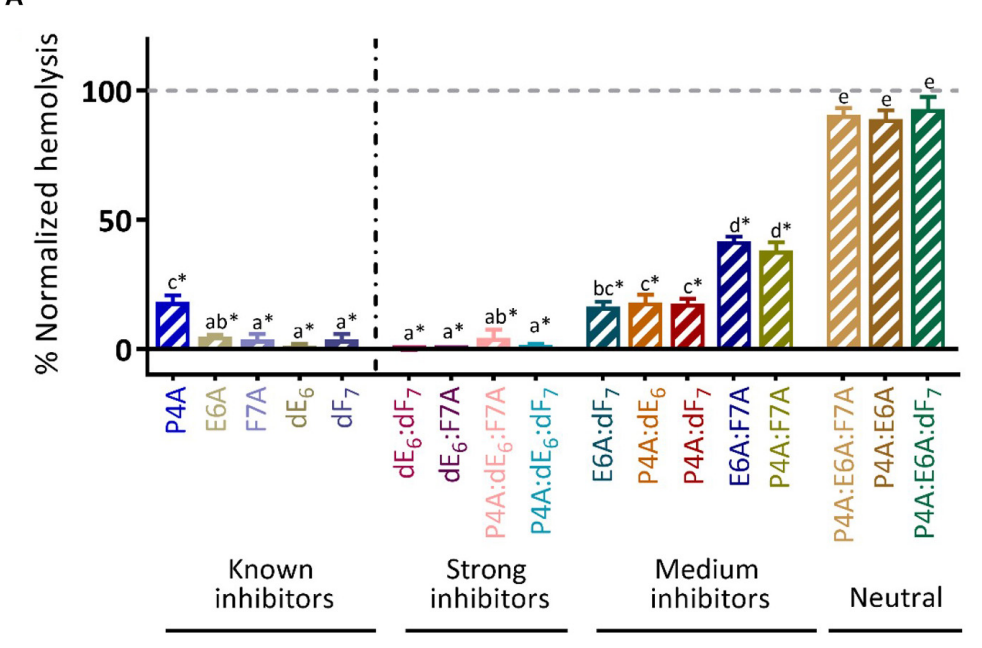

B

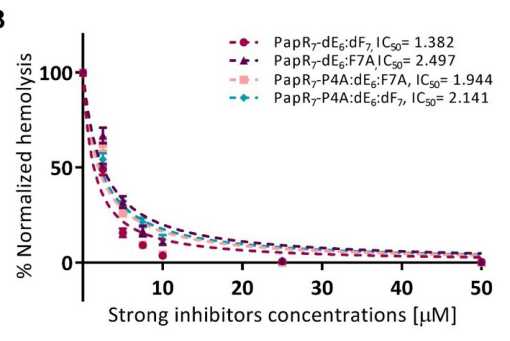

C

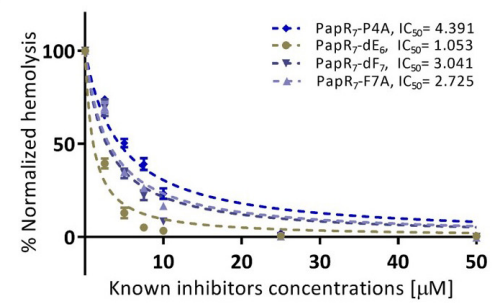

FIGURE 5 | New PapR7-derived peptide combinations inhibit Bc virulence factor. (A) Hemolytic activity on human red-blood cells of supernatant B. cereus ATCC 14579 treated cultures in $10 \mu \mathrm{M}$ of $\mathrm{PapR}_{7}$-derived peptides normalized to untreated bacterial cells at end lag phase of bacterial growth $\left(\mathrm{OD}_{600}\right.$ of $0.1 \pm 0.03$; mean \pm SEM, $n=9$ ). Hemolysis inhibition dose response curves of $B$. cereus ATCC 14579 treated supernatant cultures in different concentrations of (B) PapR 7 $\mathrm{dE}_{6}: \mathrm{dF}_{7}, \mathrm{dE}_{6}: \mathrm{F} 7 \mathrm{~A}, \mathrm{P} 4 \mathrm{~A}: \mathrm{dE}_{6}: \mathrm{dF}_{7}$, and P4A: $\mathrm{dE}_{6}: F 7 A$ and (C) known inhibitors normalized to untreated bacterial culture (mean $\left.\pm \mathrm{SEM}, n=9\right) .{ }^{*} p<0.01$ indicates a statistically significant difference between untreated B. cereus ATCC 14579 and addition of PapR7-derived peptides. Different letters indicate statistically significant differences between $\mathrm{PapR}_{7}$-derived peptide treatments $(p<0.01)$.

A

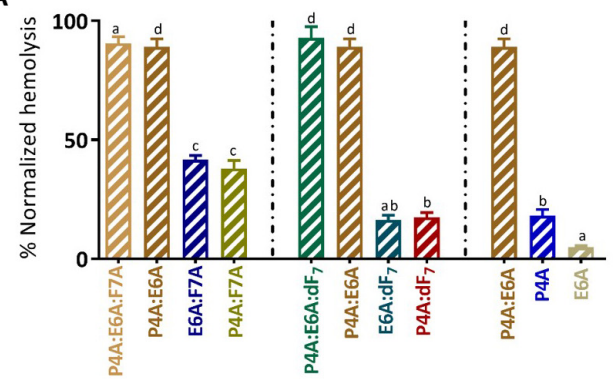

C

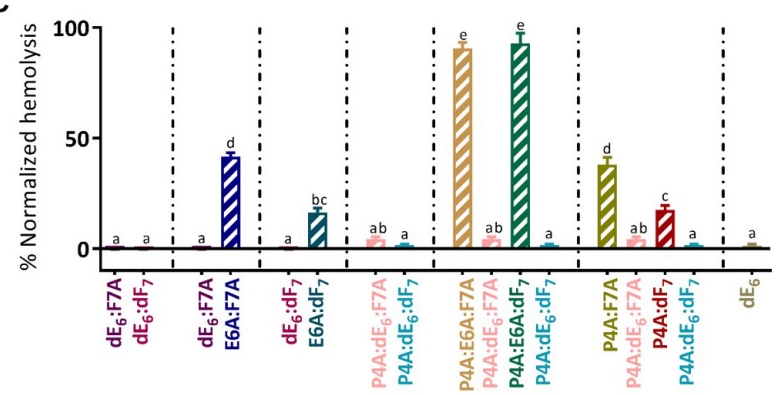

B

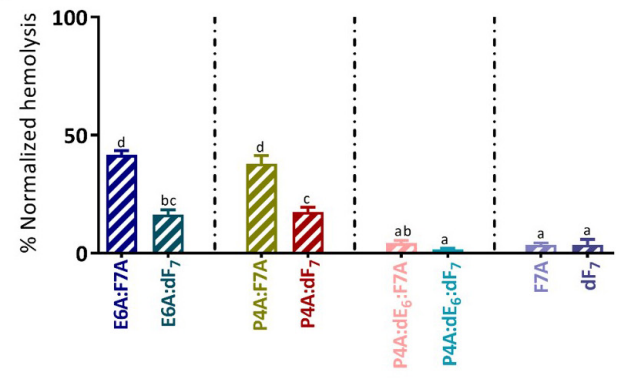

D

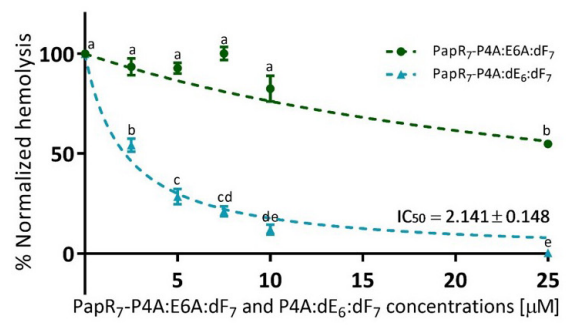

FIGURE 6 | Exploring specific combination replacements effect on Bc virulence inhibition. Hemolytic activity of supernatant B. cereus ATCC 14579 treated cultures in $10 \mu \mathrm{M}$ of PapR7-derived peptides normalized to untreated supernatants of bacterial cells at end lag phase of bacterial growth $\left(\mathrm{OD}_{600}\right.$ of $0.1 \pm 0.03$; mean $\pm \mathrm{SEM}$, $n=9$ ). Hemolytic activities on human red blood cells were classified by exploring the role of three PapR7 crucial positions in PlcR activity; (A) Role of individual and combined Pro4 or Glu6 residue replacements. (B) Effect of Phe7 replacement. (C) Importance of Glu6 and its stereoisomer substitution. Hemolysis inhibition dose response curves of $B$. cereus ATCC 14579 treated supernatant cultures in different concentrations of (D) $P a p R_{7}-P 4 A: E 6 A: d F_{7}$ and $P 4 A: d_{6}: d_{7}$ normalized to untreated bacterial culture (mean $\pm \mathrm{SEM}, n=9$ ). Different letters indicate statistically significant differences between $\mathrm{PapR}_{7}$-derived peptide treatments $(p<0.01$ ).

Interestingly, in an earlier study (Bouillaut et al., 2008; Grenha et al., 2013) the authors characterized the function and specific interactions of PapR glutamic acid with conserved residues in $\mathrm{PlcR}$. These findings support our results about the important role of Glu6 in the activity of PlcR regulon. Indeed, replacement of L-glutamic acid of $\mathrm{PapR}_{7}-\mathrm{P} 4 \mathrm{~A}: \mathrm{F} 7 \mathrm{~A}$ and $\mathrm{P} 4 \mathrm{~A}: \mathrm{dF}_{7}$ 
(corresponding ADLAFEA and ADLAFEdF), with D-glutamic acid yielded two potent PlcR antagonists; PapR $_{7}-\mathrm{P} 4 \mathrm{~A}: \mathrm{dE}_{6}: \mathrm{F} 7 \mathrm{~A}$ and $P 4 A: d_{6}: \mathrm{dF}_{7}$. Overall, these three sets of new $\mathrm{PapR}_{7}$-derived peptide combinations support previous published studies and reveal the important role of three crucial positions at designing potent PlcR antagoinsts; Pro4, Phe7 and especially Glu6 that may function to selectively allow PapR, but not other similar autoinducers, to bind PlcR.

\section{CONCLUSION}

The PapR-PlcR QS system is extensively involved in the pathogenesis of $B$. cereus, highlighting this system as an attractive target for an alternative treatment to prevent infection. We have previously reported the first five potent synthetic peptidic inhibitors of $B$. cereus PlcR-PapR QS system (Yehuda et al., 2018); three independent alanine amino acid replacements $\left(\mathrm{PapR}_{7}\right.$ - P4A, E6A, and F7A) and two D-amino acid substitutions $\left(\mathrm{PapR}_{7}-\mathrm{dE}_{6}\right.$ and $\left.\mathrm{dF}_{7}\right)$. We concluded that the critical residues for $\mathrm{PapR}_{7}-\mathrm{PlcR}$ interaction and $\mathrm{PlcR}$ activation were proline, glutamic acid and phenylalanine. To further understand their role in PlcR activity, a new set of $\mathrm{PapR}_{7}$ analogs with double and triple alanine and $\mathrm{D}$ amino acid replacements at these positions were designed and synthesized. Multiple amino acid substitutions revealed that any replacement at these positions Pro4, Glu6 and Phe7 of $\mathrm{PapR}_{7}$ derivatives, is critical for $\mathrm{PlcR}$ regulon activation in the $\triangle p a p R$ mutant strain. A comprehensive competition study of all $\mathrm{PapR}_{7}$-derived peptides combinations in lateexponential phase identified four promising QS peptidic inhibitors candidates; PapR $7-\mathrm{dE}_{6}: \mathrm{dF}_{7}$ and $\mathrm{dE}_{6}: F 7 A$ and two other analogs with additional alanine substituted $\mathrm{PapR}_{7}$ - P4A: $\mathrm{dE}_{6}: \mathrm{dF}_{7}$ and $\mathrm{P} 4 \mathrm{~A}: \mathrm{dE}_{6}: \mathrm{F} 7 \mathrm{~A}$, all contained D-Glutamic acid at position 6 of the C-terminus of heptapeptide PapR. The two potent inhibitors $\mathrm{PapR}_{7}-\mathrm{dE}_{6}: \mathrm{dF}_{7}$ and $\mathrm{dE}_{6}: \mathrm{F} 7 \mathrm{~A}$ generated similar inhibitory activity as their parent single replacement reported inhibitors $\mathrm{PapR}_{7}-\mathrm{dE}_{6}, \mathrm{dF}_{7}$ and F7A with comparable $\mathrm{IC}_{50}$ values $\cong 1-2.6 \mu \mathrm{M}$. Our results verified previous reports that inhibition through $\mathrm{PapR}_{7}$ derivatives is cell density dependent (Slamti and Lereclus, 2002; Yehuda et al., 2018). We showed that all of our new four promising QS peptidic inhibitors candidates blocked the PlcR regulon activity even after 24 -h period, when they were added at an early stage of bacterial growth $\left(\mathrm{PapR}_{7}-\mathrm{dE}_{6}: \mathrm{dF}_{7}, \mathrm{dE}_{6}: \mathrm{F} 7 \mathrm{~A}\right.$, $\mathrm{PapR}_{7}-\mathrm{P} 4 \mathrm{~A}: \mathrm{dE}_{6}: \mathrm{dF}_{7}$, and $\left.\mathrm{P} 4 \mathrm{~A}: \mathrm{dE}_{6}: \mathrm{F} 7 \mathrm{~A}\right)$. Moreover, by exposing the bacterial cells to these analogs at earlier stage $\left(\mathrm{OD}_{600}\right.$ $0.1 \pm 0.03)$ we discovered a new series of inhibitors $\left(\mathrm{PapR}_{7}\right.$ E6A:F7A, E6A:dF 7 , P4A:F7A, P4A: $\mathrm{dE}_{6}$, and P4A:dF $)$. Similar to the parent peptidic inhibitors, we hypothesized that the positive autoregulatory loop was blocked and quorum quenching was achieved throughout growth by the inhibitory multiple combinations $\mathrm{PapR}_{7}$ derivatives.

We next used a human red-blood cells hemolytic assay as a direct method to assess a QS-related phenotype linked to virulence in wild-type $B$. cereus. The inhibitory $\mathrm{PapR}_{7}$ peptidic analogs identified using the lacZ-reporter assays were even more efficient in reducing the hemolytic activity of wild type B. cereus ATCC 14579.

Our findings both corroborate and extend previous observations regarding the role of the $\mathrm{PapR}_{7}$ in $\mathrm{PlcR}$ receptor recognition; first, we showed the important role of proline or glutamic acid residues in PapR- PlcR interactions and as key in designing strong inhibitors. Second, we demonstrated that inclusion of D-Phenylalanine at Phe7 contribute to $\mathrm{PapR}_{7}$ derivatives inhibitory activities probably due to its hydrophobic features. Moreover, by interfering this Glu6 specific interactions with $\mathrm{PlcR}$, we found the potential of D-Glutamic substitution at designing potent PlcR antagonist. These findings are consistent with previous study (Slamti and Lereclus, 2005) which investigated specificity and polymorphism of $\mathrm{PlcR}$ - PapR in the $B$. cereus group. Interestingly, while all the PapR sequences from different strains of the $B$. cereus group showed divergences in their three N-terminal residues, the E6 position was conserved. In the current study we highlighted the precise and unpredictable engineering of natural pheromone in our effort to develop new Quorum Quenching agents, reflecting the trade-off between good peptide binding and lower activation. These new non-native peptides inhibitors may be applied as chemical tools to further study the role of $\mathrm{PlcR}$ and other QS in all B. cereus group members. Further, our method of single and multiple amino acid replacements might be applied to other QS system to design new anti-virulence agents.

\section{DATA AVAILABILITY}

No datasets were generated or analyzed for this study.

\section{AUTHOR CONTRIBUTIONS}

AY, LS, and EM performed the research. DL and $\mathrm{ZH}$ analyzed the data and wrote the manuscript.

\section{FUNDING}

This research project was supported by UHJ-France and the Scopus Foundation.

\section{ACKNOWLEDGMENTS}

We would like to thank Dr. John Karas for reading and improving this manuscript.

\section{SUPPLEMENTARY MATERIAL}

The Supplementary Material for this article can be found online at: https://www.frontiersin.org/articles/10.3389/fmicb.2019. 01246/full\#supplementary-material 


\section{REFERENCES}

Agaisse, H., Gominet, M., Okstad, O. A., Kolstø, A. B., and Lereclus, D. (1999). $\mathrm{PlcR}$ is a pleiotropic regulator of extracellular virulence factor gene expression in Bacillus thuringiensis. Mol. Microbiol. 32, 1043-1053. doi: 10.1046/j.13652958.1999.01419.x

Amara, N., Krom, B. P., Kaufmann, G. F., and Meijler, M. M. (2011). Macromolecular Inhibition of quorum sensing: enzymes, antibodies, and beyond. Chem. Rev. 111, 195-208. doi: 10.1021/cr100101c

Blatch, G. L., and Lässle, M. (1999). The tetratricopeptide repeat: a structural motif mediating protein-protein interactions. BioEssays 21, 932-939. doi: 10.1002/ (sici)1521-1878(199911)21:11<932::aid-bies5>3.3.co;2-e

Bottone, E. J. (2010). Bacillus cereus, a volatile human pathogen. Clin. Microbiol. Rev. 23, 382-398. doi: 10.1128/CMR.00073-79

Bouillaut, L., Perchat, S., Arold, S., Zorrilla, S., Slamti, L., Henry, C., et al. (2008). Molecular basis for group-specific activation of the virulence regulator PlcR by PapR heptapeptides. Nucleic Acids Res. 36, 3791-3801. doi: 10.1093/nar/gkn149

Chu, W. P., Wong, S. N., Que, T. L., and Lee, W. K. (2001). Meningoencephalitis caused by Bacillus cereus in a neonate. Hong Kong Med. J. 7, 89-92.

Declerck, N., Bouillaut, L., Chaix, D., Rugani, N., Slamti, L., Hoh, F., et al. (2007). Structure of PlcR: insights into virulence regulation and evolution of quorum sensing in gram-positive bacteria. Proc. Natl. Acad. Sci. U.S.A. 104, 18490-18495. doi: 10.1073/pnas.0704501104

Dubois, T., Faegri, K., Perchat, S., Lemy, C., Buisson, C., Nielsen-LeRoux, C., et al. (2012). Necrotrophism is a quorum-sensing-regulated lifestyle in Bacillus thuringiensis. PLoS Pathog. 8:e1002629. doi: 10.1371/journal.ppat.1002629

Dunny, G. M., and Leonard, B. A. (1997). Cell-cell communication in grampositive bacteria. Ann. Rev. Microbiol. 51, 527-564. doi: 10.1146/annurev.micro. 51.1.527

Erez, Z., Steinberger-Levy, I., Shamir, M., Doron, S., Stokar-Avihail, A., Peleg, Y., et al. (2017). Communication between viruses guides lysis-lysogeny decisions. Nature 541, 488-493. doi: 10.1038/nature21049

Fontaine, L., Boutry, C., De Frahan, M. H., Delplace, B., Fremaux, C., Horvath, P., et al. (2010). A novel pheromone quorum-sensing system controls the development of natural competence in Streptococcus thermophilus and Streptococcus salivarius. J. Bacteriol. 192, 1444-1454. doi: 10.1128/JB.012511259

Fontaine, L., Wahl, A., Fléchard, M., Mignolet, J., and Hols, P. (2015). Regulation of competence for natural transformation in streptococci. Infect. Genet. Evol. 33, 343-360. doi: 10.1016/j.meegid.2014.09.010

Galloway, W. R., Hodgkinson, J. T., Bowden, S., Welch, M., and Spring, D. R. (2012). Applications of small molecule activators and inhibitors of quorum sensing in Gram-negative bacteria. Trends Microbiol. 20, 449-458. doi: 10.1016/ j.tim.2012.06.003

Gaur, H., Patrick, C. C., McCullers, J. A., Flynn, P. M., Pearson, T. A., Razzouk, B. I, et al. (2001). Bacillus cereus bacteremia and meningitis in immunocompromised children. Clin. Infect. Dis. 32, 1456-1462. doi: 10.1086/ 320154

Gohar, M., Faegri, K., Perchat, S., Ravnum, S., Økstad, O. A., Gominet, M., et al. (2008). The PlcR virulence regulon of Bacillus cereus. PLoS One 30:e2793. doi: 10.1371/journal.pone.0002793

Gominet, M., Slamti, L., Gilois, N., Rose, M., and Lereclus, D. (2001). Oligopeptide permease is required for expression of the Bacillus thuringiensis plcR regulon and for virulence. Mol. Microbiol. 40, 963-975. doi: 10.1046/j.1365-2958.2001. 02440.x

Grandclément, C., Tannières, M., Moréra, S., Dessaux, Y., and Faure, D. (2015). Quorum quenching: role in nature and applied developments. FEMS Microbiol. Rev. 40, 86-116. doi: 10.1093/femsre/fuv038

Granum, P. E., and Lund, T. (1997). Bacillus cereus and its food poisoning toxins. FEMS Microbiol. Lett. 157, 223-228. doi: 10.1016/s0378-1097(97)00438-2

Gray, B., Hall, P., and Gresham, H. (2013). Targeting agr- and agr-like quorum sensing systems for development of common therapeutics to treat multiple gram-positive bacterial infections. Sensors 13, 5130-5166. doi: 10.3390/ s130405130

Grenha, R., Slamti, L., Nicaise, M., Refes, Y., Lereclus, D., and Nessler, S. (2013). Structural basis for the activation mechanism of the PlcR virulence regulator by the quorum-sensing signal peptide PapR. Proc. Natl. Acad. Sci. 110, 1047-1052. doi: 10.1073 /pnas. 1213770110
Helgason, E., Okstad, O. A., Caugant, D. A., Johansen, H. A., Fouet, A., Mock, M., et al. (2000). Bacillus anthracis, Bacillus cereus, and Bacillus thuringiensisone species on the basis of genetic evidence. Appl. Environ. Microbiol. 66, 2627-2630. doi: 10.1128/AEM.66.6.2627-2630.2000

Hentzer, M., Wu, H., Andersen, J. B., Riedel, K., Rasmussen, T. B., Bagge, N., et al. (2003). Attenuation of Pseudomonas aeruginosa virulence by quorum sensing inhibitors. EMBO J. 22, 3803-3815. doi: 10.1093/emboj/cdg366

Hoffmaster, A. R., Ravel, J., Rasko, D. A., Chapman, G. D., Chute, M. D., Marston, C. K., et al. (2004). Identification of anthrax toxin genes in a Bacillus cereus associated with an illness resembling inhalation anthrax. Proc. Natl. Acad. Sci. U.S.A. 101, 8449-8454. doi: 10.1073/pnas.0402414101

Huillet, E., Tempelaars, M. H., André-Leroux, G., Wanapaisan, P., Bridoux, L., Makhzami, S., et al. (2012). PlcRa, a new quorum-sensing regulator from bacillus cereus, plays a role in oxidative stress responses and cysteine metabolism in stationary phase. PLoS One 7:e51047. doi: 10.1371/journal.pone. 0051047

Ivanova, N., Sorokin, A., Anderson, I., Galleron, N., Candelon, B., Kapatral, V., et al. (2003). Genome sequence of Bacillus cereus and comparative analysis with Bacillus anthracis. Nature 423, 87-91. doi: 10.1038/nature01582

Kalia, V. C. (2013). Quorum sensing inhibitors: an overview. Biotechnol. Adv. 31, 224-245. doi: 10.1016/j.biotechadv.2012.10.004

Klee, S. R., Özel, M., Appel, B., Boesch, C., Ellerbrok, H., Jacob, D., et al. (2006). Characterization of Bacillus anthracis-like bacteria isolated from wild great apes from Cǒte d'Ivoire and Cameroon. J. Bacteriol. 188, 5333-5344. doi: 10.1128/JB. 00303-306

Kotiranta, A., Lounatmaa, K., and Haapasalo, M. (2000). Epidemiology and pathogenesis of Bacillus cereus infections. Microb. Infect. 2, 189-198. doi: 10. 1016/S1286-4579(00)00269-260

Lazazzera, B. A., Solomon, J. M., and Grossman, A. D. (1997). An exported peptide functions intracellularly to contribute to cell density signaling in B. subtilis. Cell 89, 917-925. doi: 10.1016/S0092-8674(00)80277-80279

Lereclus, D., Agaisse, H., Gominet, M., Salamitou, S., and Sanchis, V. (1996). Identification of a Bacillus thuringiensis gene that positively regulates transcription of the phosphatidylinositol-specific phospholipase $\mathrm{C}$ gene at the onset of the stationary phase. J. Bacteriol. 178, 2749-2756. doi: 10.1128/jb.178. 10.2749-2756.1996

Lereclus, D., Arantès, O., Chaufaux, J., and Lecadet, M. (1989). Transformation and expression of a cloned delta-endotoxin gene in Bacillus thuringiensis. FEMS Microbiol. Lett. 51, 211-217. doi: 10.1016/0378-1097(89)90511-9

Lobel, L., Sigal, N., Borovok, I., Belitsky, B. R., Sonenshein, A. L., and Herskovits, A. A. (2015). The metabolic regulator CodY links Listeria monocytogenes metabolism to virulence by directly activating the virulence regulatory gene prfA. Mol. Microbiol. 95, 624-644. doi: 10.1111/mmi.12890

Mashburn-Warren, L., Morrison, D. A., and Federle, M. J. (2010). A novel doubletryptophan peptide pheromone controls competence in Streptococcus spp. via an Rgg regulator. Mol. Microbiol. 78, 589-606. doi: 10.1111/j.1365-2958.2010. 07361.x

Mignolet, J., Fontaine, L., Sass, A., Nannan, C., Mahillon, J., Coenye, T., et al. (2018). Circuitry rewiring directly couples competence to predation in the gut dweller Streptococcus salivarius. Cell Rep. 22, 1627-1638. doi: 10.1016/j.celrep. 2018.01.055

Miller, M. B., and Bassler, B. L. (2001). Quorum sensing in bacteria. Ann. Rev. Microbiol. 55, 165-199. doi: 10.1146/annurev.micro.55.1.165

Neiditch, M. B., Capodagli, G. C., Prehna, G., and Federle, M. J. (2017). Genetic and structural analyses of RRNPP intercellular peptide signaling of gram-positive bacteria. Ann. Rev. of Genet. 51, 311-333. doi: 10.1146/annurev-genet-120116123507

ØKstad, O. A., Gominet, M., Purnelle, B., Rose, M., Lereclus, D., and Kolstø, A. B. (1999). Sequence analysis of three Bacillus cereus loci carrying PlcRregulated genes encoding degradative enzymes and enterotoxin. Microbiology 145, 3129-3138. doi: 10.1099/00221287-145-11-3129

Perchat, S., Dubois, T., Zouhir, S., Gominet, M., Poncet, S., Lemy, C., et al. (2011). A cell-cell communication system regulates protease production during sporulation in bacteria of the Bacillus cereus group. Mol. Microbiol. 82, 619-633. doi: 10.1111/j.1365-2958.2011.07839.x

Perego, M. (2013). Forty years in the making: understanding the molecular mechanism of peptide regulation in bacterial development. PLoS Biol. 11:e1001516. doi: 10.1371/journal.pbio. 1001516 
Perego, M., and Brannigan, J. A. (2001). Pentapeptide regulation of aspartylphosphate phosphatases. Peptides 22, 1541-1547. doi: 10.1016/S0196-9781(01) 00490-499

Priest, F. G., Kaji, D. A., Rosato, Y. B., and Canhos, V. P. (1994). Characterization of Bacillus thuringiensis and related bacteria by ribosomal RNA gene restriction fragment length polymorphisms. Microbiology 140, 1015-1022. doi: 10.1099/ 13500872-140-5-1015

Rajput, A., Kaur, K., and Kumar, M. (2016). SigMol: repertoire of quorum sensing signaling molecules in prokaryotes. Nucleic Acids Res. 44, D634-D639. doi: $10.1093 /$ nar/gkv1076

Ramarao, N., and Sanchis, V. (2013). The pore-forming haemolysins of Bacillus cereus: a review. Toxins 5, 1119-1139. doi: 10.3390/toxins5061119

Rasko, D. A., Altherr, M. R., Han, C. S., and Ravel, J. (2005). Genomics of the Bacillus cereus group of organisms. FEMS Microbiol. Rev. 29, 303-329. doi: 10.1016/j.femsre.2004.12.005

Rasmussen, T. B., and Givskov, M. (2006). Quorum sensing inhibitors: a bargain of effects. Microbiology 152, 895-904. doi: 10.1099/mic.0.28601-28600

Rossi, G. A. M., Aguilar, C. E. G., Silva, H. O., and Vidal, A. M. C. (2018). Bacillus cereus group: genetic aspects related to food safety and dairy processing. Arquivos do Instituto Biológico 85, e0232017. doi: 10.1590/18081657000232017

Salamitou, S., Ramisse, F., Brehelin, M., Bourguet, D., Gilois, N., Gominet, M., et al. (2000). The plcR regulon is involved in the opportunistic properties of Bacillus thuringiensis and Bacillus cereus in mice and insects. Microbiology 146, 2825-2832. doi: 10.1099/00221287-146-11-2825

Shi, K., Brown, C. K., Gu, Z.-Y., Kozlowicz, B. K., Dunny, G. M., Ohlendorf, D. H., et al. (2005). Structure of peptide sex pheromone receptor $\operatorname{PrgX}$ and $\mathrm{PrgX} /$ pheromone complexes and regulation of conjugation in Enterococcus faecalis. Proc. Natl. Acad. Sci. U.S.A. 102, 18596-18601. doi: 10.1073/pnas. 0506163102

Slamti, L., and Lereclus, D. (2002). A cell-cell signaling peptide activates the $\mathrm{PlcR}$ virulence regulon in bacteria of the Bacillus cereus group. EMBO J. 21, 4550-4559. doi: 10.1093/emboj/cdf450

Slamti, L., and Lereclus, D. (2005). Specificity and polymorphism of the PlcR-PapR quorum-sensing system in the Bacillus cereus group specificity and polymorphism of the PlcR-PapR quorum-sensing system in the Bacillus cereus Group. J. Bacteriol. 187, 1182-1187. doi: 10.1128/JB.187. 3.1182

Slamti, L., Perchat, S., Gominet, M., Vilas-Bôas, G., Fouet, A., Mock, M., et al. (2004). Distinct mutations in PlcR explain why some strains of the Bacillus cereus group are nonhemolytic. J. Bacteriol. doi: 10.1128/JB.186.11.3531-3538. 2004

Slamti, L., Perchat, S., Huillet, E., and Lereclus, D. (2014). Quorum sensing in Bacillus thuringiensis is required for completion of a full infectious cycle in the insect. Toxins 6, 2239-2255. doi: 10.3390/toxins6082239

Stenfors Arnesen, L. P., Fagerlund, A., and Granum, P. E. (2008). From soil to gut: Bacillus cereus and its food poisoning toxins. FEMS Microbiol. Rev. 32, 579-606. doi: 10.1111/j.1574-6976.2008.00112.x

Suga, H., and Smith, K. M. (2003). Molecular mechanisms of bacterial quorum sensing as a new drug target. Curr. Opin. Chem. Biol. 7, 586-591. doi: 10.1016/ j.cbpa.2003.08.001

Sully, E. K., Malachowa, N., Elmore, B. O., Alexander, S. M., Femling, J. K., Gray, B. M., et al. (2014). Selective chemical inhibition of agr quorum sensing in Staphylococcus aureus promotes host defense with minimal impact on resistance. PLoS Pathog. 10:e1004174. doi: 10.1371/journal.ppat. 1004174
Suzuki, A., Mori, M., Sakagami, Y., Isogai, A., Fujino, M., Kitada, C., et al. (1984). Isolation and structure of bacterial sex pheromone, cPD1. Science 226, 849-850. doi: $10.1126 /$ science. 6436978

Tal-Gan, Y., Ivancic, M., Cornilescu, G., Cornilescu, C. C., and Blackwell, H. E. (2013a). Structural characterization of native autoinducing peptides and abiotic analogues reveals key features essential for activation and inhibition of an agrc quorum sensing receptor in Staphylococcus aureus. J. Am. Chem. Soc. 135, 18436-18444. doi: 10.1021/ja407533e

Tal-Gan, Y., Stacy, D. M., Foegen, M. K., Koenig, D. W., and Blackwell, H. E. (2013b). Highly potent inhibitors of quorum sensing in Staphylococcus aureus revealed through a systematic synthetic study of the group-III autoinducing peptide. J. Am. Chem. Soc. 135, 7869-7882. doi: 10.1021/ja3112115

Tal-Gan, Y., Ivancic, M., Cornilescu, G., Yang, T., and Blackwell, H. E. (2016). Highly stable, amide-bridged autoinducing peptide analogues that strongly inhibit the AgrC quorum sensing receptor in Staphylococcus aureus. Angew. Chem. Int. Ed. Engl. 55, 8913-8917. doi: 10.1002/anie. 201602974

Tal-Gan, Y., Stacy, D. M., and Blackwell, H. E. (2014). N-Methyl and peptoid scans of an autoinducing peptide reveal new structural features required for inhibition and activation of AgrC quorum sensing receptors in Staphylococcus aureus. Chem. Commun. 50, 3000-3003. doi: 10.1039/c4cc00117f

Vilas-Boas, G., Sanchis, V., Lereclus, D., Lemos, M. V., and Bourguet, D. (2002). Genetic differentiation between sympatric populations of Bacillus cereus and Bacillus thuringiensis. Appl. Environ. Microbiol. 68, 1414-1424. doi: 10.1128/ AEM.68.3.1414

Wintjens, R., and Rooman, M. (1996). Structural classification of HTH DNAbinding domains and protein-DNA interaction modes. J. Mol. Biol. 262, 294-313. doi: 10.1006/jmbi.1996.0514

Wynendaele, E., Bronselaer, A., Nielandt, J., D’Hondt, M., Stalmans, S., Bracke, N., et al. (2013). Quorumpeps database: chemical space, microbial origin and functionality of quorum sensing peptides. Nucleic Acids Res. 41, D655-D659. doi: 10.1093/nar/gks1137

Yang, Y., Koirala, B., Sanchez, L. A., Phillips, N. R., Hamry, S. R., and Tal-Gan, Y. (2017). Structure-activity relationships of the competence stimulating peptides (CSPs) in Streptococcus pneumoniae reveal motifs critical for intra-group and cross-group ComD receptor activation. ACS Chem. Biol. 12, 1141-1151. doi: 10.1021/acschembio.7b00007

Yehuda, A., Slamti, L., Bochnik-Tamir, R., Malach, E., Lereclus, D., and Hayouka, Z. (2018). Turning off Bacillus cereus quorum sensing system with peptidic analogs. Chem. Commun. 54, 9777-9780. doi: 10.1039/c8cc05496g

Zheng, F., Ji, H., Cao, M., Wang, C., Feng, Y., Li, M., et al. (2011). Contribution of the Rgg transcription regulator to metabolism and virulence of Streptococcus suis serotype 2. Infect. Immun. 79, 1319-1328. doi: 10.1128/IAI. 00193-10

Conflict of Interest Statement: The authors declare that the research was conducted in the absence of any commercial or financial relationships that could be construed as a potential conflict of interest.

Copyright (c) 2019 Yehuda, Slamti, Malach, Lereclus and Hayouka. This is an openaccess article distributed under the terms of the Creative Commons Attribution License (CC BY). The use, distribution or reproduction in other forums is permitted, provided the original author(s) and the copyright owner(s) are credited and that the original publication in this journal is cited, in accordance with accepted academic practice. No use, distribution or reproduction is permitted which does not comply with these terms. 